\title{
Article \\ Physico-Chemical Characteristics and In Vitro Gastro-Small Intestinal Digestion of New Zealand Ryegrass Proteins
}

\author{
Lovedeep Kaur ${ }^{1,2}{ }^{\circledR}$, Harmandeepsingh Lamsar ${ }^{1}$, Ignacio F. López ${ }^{3}$, Manon Filippi ${ }^{1,2}$, Dayna Ong Shu Min ${ }^{1}{ }^{(}$, \\ Kévin Ah-Sing ${ }^{1,2}$ and Jaspreet Singh ${ }^{1,2, *}$ \\ 1 School of Food and Advanced Technology, Massey University, Palmerston North 4442, New Zealand; \\ L.kaur@massey.ac.nz (L.K.); hrmn87nz@gmail.com (H.L.); manon.filippi@gmail.com (M.F.); \\ 1601298@sit.singaporetech.edu.sg (D.O.S.M.); kevin.ahsing@gmail.com (K.A.-S.) \\ 2 Riddet Institute, Massey University, Palmerston North 4442, New Zealand \\ 3 School of Agriculture and Environment, Massey University, Palmerston North 4442, New Zealand; \\ I.F.Lopez@massey.ac.nz \\ * Correspondence: J.x.singh@massey.ac.nz; Tel.: +64-6-951-7290
}

check for updates

Citation: Kaur, L.; Lamsar, H.; López, I.F.; Filippi, M.; Ong Shu Min, D.; Ah-Sing, K.; Singh, J.

Physico-Chemical Characteristics and In Vitro Gastro-Small Intestinal Digestion of New Zealand Ryegrass Proteins. Foods 2021, 10, 331. https://doi.org/10.3390/foods 10020331

Academic Editors: Francisco Javier Moreno

Received: 28 December 2020

Accepted: 25 January 2021

Published: 4 February 2021

Publisher's Note: MDPI stays neutral with regard to jurisdictional claims in published maps and institutional affiliations.

Copyright: (c) 2021 by the authors. Licensee MDPI, Basel, Switzerland. This article is an open access article distributed under the terms and conditions of the Creative Commons Attribution (CC BY) license (https:// creativecommons.org/licenses/by/ $4.0 /)$.

\begin{abstract}
Being widely abundant, grass proteins could be a novel source of plant proteins for human foods. In this study, ryegrass proteins extracted using two different approaches-chemical and enzymatic extraction, were characterised for their physico-chemical and in vitro digestion properties. A New Zealand perennial ryegrass cultivar Trojan was chosen based on its higher protein and lower dry matter contents. Grass protein concentrate (GPC) with protein contents of approximately 55 and $44 \%$ were prepared using the chemical and enzymatic approach, respectively. The thermal denaturation temperature of the GPC extracted via acid precipitation and enzymatic treatment was found to be $68.0 \pm 0.05{ }^{\circ} \mathrm{C}$ and $66.15 \pm 0.03{ }^{\circ} \mathrm{C}$, respectively, showing significant differences in protein's thermal profile according to the method of extraction. The solubility of the GPC was highly variable, depending on the temperature, $\mathrm{pH}$ and salt concentration of the dispersion. The solubility of the GPC extracted via enzymatic extraction was significantly lower than the proteins extracted via the chemical method. Digestion of raw GPC was also studied via a gastro-small intestinal in vitro digestion model and was found to be significantly lower, in terms of free amino $\mathrm{N}$ release, for the GPC prepared through acid precipitation. These results suggest that the physico-chemical and digestion characteristics of grass proteins are affected by the extraction method employed to extract the proteins. This implies that selection of an appropriate extraction method is of utmost importance for achieving optimum protein functionality during its use for food applications.
\end{abstract}

Keywords: grass protein concentrate; solubility; in vitro digestion; thermal denaturation

\section{Introduction}

Plants have been used in the human diet as sources of energy and nutrients for many years. Plants protein market is growing rapidly as plants are seen as a sustainable solution to meet nutritional needs of the growing world population [1]. Perennial crops such as grasses can generate a large amount of biomass and being widely abundant, could be a potential source of protein for human consumption. The enzyme, 1,5-bisphosphate carboxylase oxygenase (RuBisCO), which is a chloroplastic protein, makes up approximately $50 \%$ of the protein extracted from the leaf [2,3]. Other proteins present in green leaves are lipoproteins, structural proteins, pigment bound proteins and enzymes [2].

As $\mathrm{RuBisCO}$ is the main protein component in grass, it determines the functionality and nutritional value of grass protein products. It has been reported to possess an excellent complement of essential amino acids and is very rich in tryptophan, leucine, tyrosine and phenylalanine compared with other food proteins and the FAO/WHO reference pattern [2]. $\mathrm{RuBisCO}$ has also been reported to possess desirable functional properties such as gelation, foaming, and emulsification which might enable food processors to successfully incorporate 
the protein into a number of different food systems [2]. However, extraction processes greatly influence the solubility, denaturation state and composition of protein isolates. This in turn influence their functional properties such as gelation, water binding, emulsifying and foaming capacities, which are relevant for food applications [4]. Moreover, the plant species from which the protein is extracted play a significant part in affecting results [5]. The solubility of RuBisCO extracted via acid precipitation from alfalfa, soybean leaf, sugar beet leaf and tobacco varied greatly, depending on the solvent used, $\mathrm{pH}$, temperature, ionic strength, and protein concentration [6]. The use of antioxidants such as sodium sulphite during protein extraction has been reported to increase the soluble RuBisCO content in red clover possibly by inactivation of polyphenol oxidase enzyme thereby preventing cross-linking between polyphenols and soluble RuBisCO [7].

A range of conventional solvent based protein extraction methods are predominantly being used in the food sector. Both dry and wet protein extraction techniques require cell disruption as initial phase to allow protein release from protein bodies inside plant cells. Classically, cell disruption is performed by mechanical methods (e.g., grinding, milling) or by thermal and chemical treatments. However, due to high sensitivity of proteins to heat or solvent use, novel processing technologies have emerged and used for cell disruption demonstrating more efficient yield, extraction time, costs and environmental impact [8]. Some of the most promising techniques are ultrasound- and enzyme-assisted extraction, microwave-assisted extraction, pulsed electric field assisted extraction, supercritical fluid extraction and pressurised liquid extraction $[9,10]$.

Enzyme assisted extraction of biomolecules from plants has been considered to be a potential alternative to conventional solvent extraction methods and is gaining more attention because of being an efficient, benign, sustainable and eco-friendly extraction technology [11]. Routine extraction processes are not able to access the components which are dispersed in the cell cytoplasm of plant matrices and retained in the polysaccharidelignin network by hydrogen or hydrophobic bonding [12] The addition of enzymes like cellulase, hemicellulase, pectinase and $\alpha$-amylase during extraction enhances recovery by the cell wall breakdown and hydrolysing the structural polysaccharides and lipid bodies [12]. Various factors including enzyme composition and concentration, particle size of plant materials, solid to water ratio, and hydrolysis time are recognised as key factors for extraction [9]. Enzyme-assisted protein extraction is associated with irreversible carbohydrate-protein matrix disruption and requires adjustment of process parameters such as $\mathrm{pH}$ and temperature; but involves long processing time, high operational costs and high energy consumption [8]. However, it has lower environmental impact and considered a milder extraction method when compared to acid and alkaline assisted extraction methods [13]. Moreover, products obtained from enzyme-assisted extraction are considered to be of superior and preserved quality and more suitable for human consumption [8].

The aim of the present study was to compare the physico-chemical properties and in vitro digestibility of grass protein concentrate (GPC) extracted via acid precipitation and enzyme assisted extraction. The Trojan cultivar, a perennial ryegrass (Lolium perenne L.) which was released in New Zealand in 2005, was chosen. This perennial ryegrass comes from a re-selection from the cultivar Tolosa which delivered excellent persistence. Trojan has a better protein content ( $24 \%$ protein dry basis) and provide a higher total dry matter yield by producing $9 \%$ more than standard ryegrass across all seasons [14].

There is no regulatory status for a grass protein concentrate. However, the Codex Alimentarius Commission (Codex general standard 174-1989; joint FAP/WHO Food standards Programme) [15] on Vegetable Products (CCVP) has developed an international general standard for vegetable protein products (VPP). The VPP are defined as "food products produced by the reduction or removal from vegetable materials of certain of the major non-protein constituents (water, oil, starch, other carbohydrates) in a manner to achieve a protein content of $40 \%$ (dry weight basis) or over" [15]. 


\section{Materials and Methods}

\subsection{Raw Materials and Chemicals}

The Trojan cultivar of perennial ryegrass, developed in New Zealand, was used for the experiments. The enzyme used for the extraction was Viscozyme $L$, a multi-enzyme complex from Aspergillus spp. containing carbohydrases including arabanase, cellulase, $\beta$ glucanase, hemicellulase and xylanase (V2010-250mL, Sigma Aldrich, Schnelldorf, Bavaria, Germany) and stored at $5{ }^{\circ} \mathrm{C}$. This enzyme complex is capable of hydrolysing structural cell wall polysaccharides, improving extraction and obtaining protein concentrate [16]. It complies with the recommended purity specifications for food-grade enzymes given by the joint FAO/WHO Expert Committee on Food Additives (JECFA) and the Food Chemical Codex (FCC). All chemicals used in the study were of analytical grade.

\subsection{Preparation of Grass Protein Concentrate Using Acid Precipitation}

Trojan ryegrass was harvested and frozen at $-20{ }^{\circ} \mathrm{C}$ until further required. GPC was extracted and precipitated using a method described by Zhang, et al. [17] with some modifications. The frozen grass was mixed with distilled water $(58.8 \% w / v)$ and $0.1 \mathrm{M}$ $\mathrm{NaOH}(26 \% v / w)$. The mixture was then ground using a wet disintegrator (C200, JEFFRESS Engineering Pty Ltd., Dry Creek, Australia) at $6000 \mathrm{rpm}$ for $10 \mathrm{~min}$. The mixture was pressed through a cheese press (Massey University, Palmerston North, New Zealand) and the filtrate was collected. The process was then repeated with the residue obtained from the filtration process, and the filtrate was centrifuged (Westfalia CTC-03-107). Precipitation was then carried out at $\mathrm{pH} 3.5$ and centrifuged again to collect the protein precipitate. The protein precipitate was freeze-dried, vacuum packaged and stored at $4{ }^{\circ} \mathrm{C}$ until analysed.

\subsection{Preparation of Grass Protein Concentrate Using Enzyme Treatment}

Based on preliminary work, a new extraction process stated in Figure 1 was standardised for extraction of GPC using the enzyme treatment. The frozen grass was ground with 1.5 times of water using a wet disintegrator (C200, JEFFRESS Engineering Pty Ltd., Dry Creek, Australia) for $10 \mathrm{~min}$. Then the grass slurry was put in a Cheese Press (Massey University, Palmerston North, New Zealand) to remove all of the solids part. The process was repeated with the residue obtained from the filtration process by adding additional water $(9000 \mathrm{~mL})$.

The solids parts obtained (R1) were subjected to enzyme treatment for $3 \mathrm{~h}$. This treatment was performed using the multi-enzyme complex Viscozyme $\mathrm{L}$ at $1 \%$ concentration. The enzyme solution to wet grass ratio was 7:1 $(v / w)$, while the $\mathrm{pH}$ and temperature were maintained as 5 and $45^{\circ} \mathrm{C}$, respectively. These conditions were chosen based on preliminary experimentation to get better protein yield. The temperature of the mixture was maintained using an Electric Jacketed Pan and the $\mathrm{pH}$ was adjusted using $6 \mathrm{M} \mathrm{HCl}$. After $3 \mathrm{~h}$ of treatment, the mixture was put in the industrial press again, ground with water $(10 \mathrm{~L})$ and pressed through a cheese press again.

Then the retentate/solids obtained (R2) were subjected to a second enzyme treatment under the same operating conditions as the first treatment. After further $3 \mathrm{~h}$ of treatment, the mixture was put in the industrial press, re-ground with water $(5 \mathrm{~L})$ and pressed through a cheese press again.

All the filtrates obtained (F1, F2 and F3; Figure 1) were collected, mixed and centrifuged using a Westfalia Separator CTC-03-107 (GEA, Oelde, Germany). The sediment obtained was frozen and freeze-dried (FD18LT Freeze Drier, Cuddon, Blenheim, New Zealand). Then the powder was ground in a coffee grinder (BCG200, Breville ${ }^{\circledR}$, Sydney, Australia), vacuum packaged and stored at $-4{ }^{\circ} \mathrm{C}$ until analysed. 


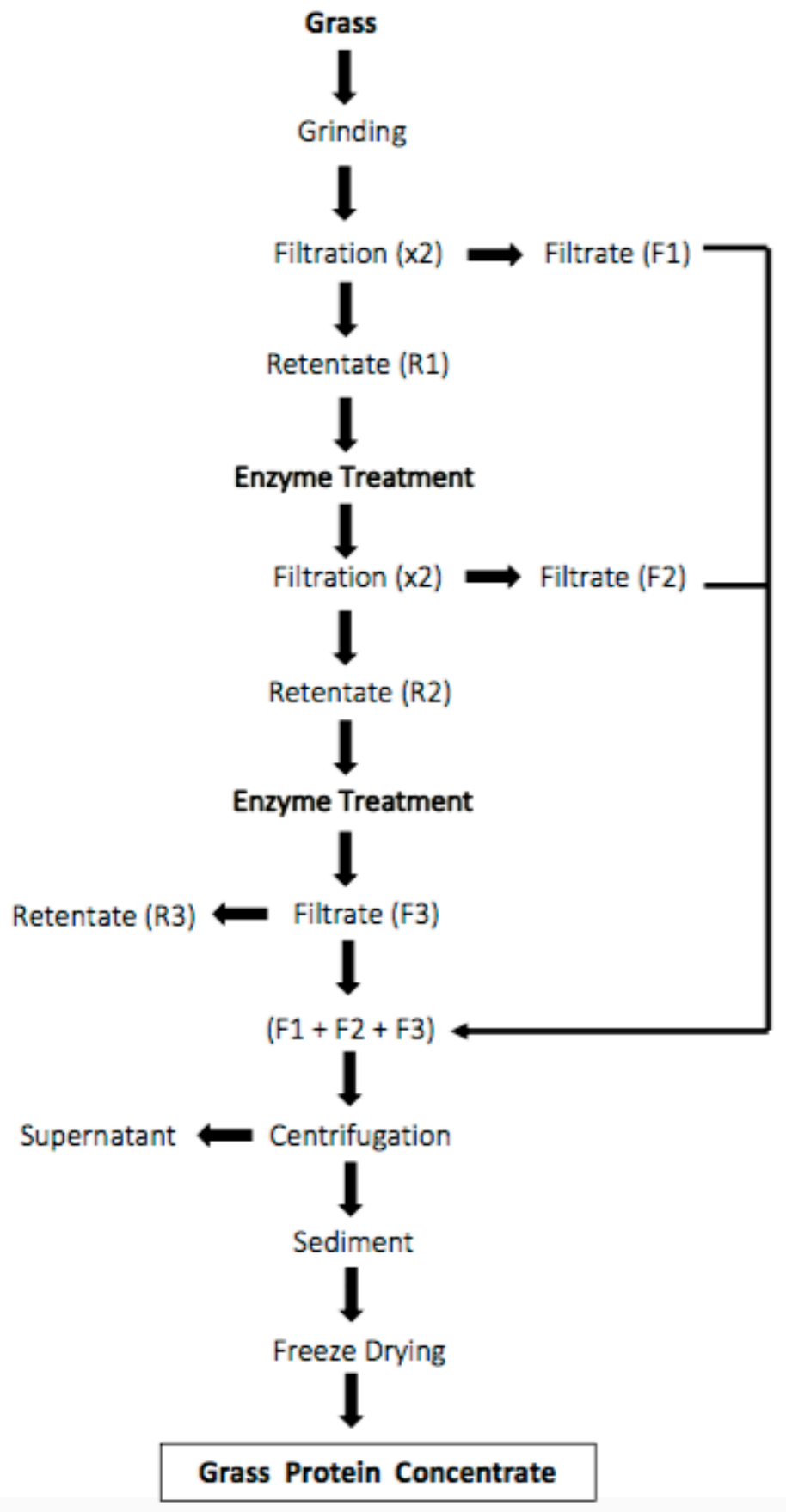

Figure 1. Process flow chart for protein extraction by enzyme treatment.

\subsection{Proximate Analysis}

The moisture content was determined using convection oven at $105{ }^{\circ} \mathrm{C}$ (AOAC 930.15925.10) [18] and calculated using the weight difference between the samples before and after drying. The protein content of samples was determined using the Kjeldahl method (AOAC 978.04) [18] and the nitrogen conversion factor of 5.83 was applied [19].

GPC prepared through acid precipitation was also subjected to nutritional analysis, including ash; fat; total, soluble and insoluble dietary fibre; carbohydrate; and minerals (calcium, potassium, magnesium, sodium and iron) using AOAC 942.05; AOAC 2003.06; Megazyme AOAC 991.45 [18]; starch + sugars method; and inductively coupled plasmaoptical emission spectroscopy (ICP-OES) [20] methods, respectively. 


\subsection{Differential Scanning Calorimetry}

The methodology for the DSC analysis was adapted from Ahmad, et al. [21], with slight modifications. Twelve (12 mg) milligrams of GPC was weighed into aluminium pans (TA Instruments, TZero 901684.901), followed by the addition of $18 \mathrm{mg}$ of Milli-Q water to obtain $30 \mathrm{mg}$ of $40 \% w / v$ GPC concentration. The pans were then hermetically sealed and left overnight at $23 \pm 2{ }^{\circ} \mathrm{C}$. Scans were then conducted using a differential scanning calorimeter (Q2000, TA Instruments, New Castle, DE, USA) in triplicates, with heating from 20 to $100{ }^{\circ} \mathrm{C}$ at a rate of $5{ }^{\circ} \mathrm{C} / \mathrm{min}$. The DSC was calibrated with indium and gallium, with empty aluminium pans used as reference. The thermal properties of the GPC were then analysed using an analytical software (TA Universal Analysis, TA Instruments, New Castle, DE, USA). The thermal denaturation temperature $\left(T_{d}\right)$ was determined based on the highest peak of the endothermic curve, and the enthalpy was calculated from the area below the transition peak.

\subsection{Effect of $\mathrm{pH}$ and Temperature on Solubility of Grass Protein Concentrate}

Solubility of the protein powder was determined using the methods from Bolontrade, et al. [22], with slight modifications. In short, GPC was first dissolved $(1 \%, w / v)$ in distilled water. To determine the effect of $\mathrm{pH}$ on solubility, the $\mathrm{pH}$ of the solution was then adjusted using $1 \mathrm{M} \mathrm{HCl}$ or $\mathrm{NaOH}$ to $\mathrm{pH} 1.5-9(\mathrm{pH} 7,9,10$ and 12 for GPC prepared through enzyme treatment). For effect of salt $(\mathrm{NaCl})$ concentration, GPC $(1 \%, w / v)$ was dissolved in $0.1-1 \mathrm{M}$ $\mathrm{NaCl}$ solutions with the $\mathrm{pH}$ adjusted to 9 . The solutions were then mixed at $300 \mathrm{rpm}$ for $1 \mathrm{~h}$ at $20^{\circ} \mathrm{C}$.

For studying the effect of temperature, GPC was dissolved in distilled water $(1 \%$, $w / v$ ) with the $\mathrm{pH}$ adjusted to 7 and 9 (pH 9 only tested for GPC prepared via enzyme treatment), and left to stir at $300 \mathrm{rpm}$ for $1 \mathrm{~h}$ using a magnetic stirrer, at $20^{\circ} \mathrm{C}, 40^{\circ} \mathrm{C}, 60^{\circ} \mathrm{C}$, $80{ }^{\circ} \mathrm{C}$ or $100{ }^{\circ} \mathrm{C}$ [23]. To prevent from moisture loss during heating, the beakers were covered with aluminium foil. The $\mathrm{pH}$ was adjusted again after $30 \mathrm{~min}$ of heating treatment. The $\mathrm{pH}$ of the solution decreased by $2 \mathrm{pH}$ units along the heating that could be due to a conformational change of the protein induced by thermal denaturation [24]. All samples were then centrifuged at $2400 \times g$ for $15 \mathrm{~min}$, and the supernatant was tested for soluble protein concentration (Ps) using the Kjeldahl method, AOAC 978.04 [18]. Results were expressed as percentage of solubility, \%S:

$$
\text { Solubility }(\%)=\frac{P S}{\text { Initial protein concentration }} \times 100
$$

A pH-shifting treatment was applied to GPC solution prepared by enzyme treatment $(1 \%, w / v)$ by following the method proposed by Yildiz [25] with slight modification. GPC solution was adjusted to $\mathrm{pH} 10$ and 12 with $1 \mathrm{M} \mathrm{NaOH}$. The solutions were mixed at $300 \mathrm{rpm}$ for $1 \mathrm{~h}$ at $20^{\circ} \mathrm{C}$ before adjusting the $\mathrm{pH}$ back to $\mathrm{pH} 7$ with $6 \mathrm{M} \mathrm{HCl}$. Then the effect of temperature on GPC solution treated by $\mathrm{pH}$-shifting at $\mathrm{pH} 12$ was determined on protein solubility as described in above.

\subsection{Determination of Gastro-Small Intestinal In Vitro Protein Digestibility}

The GPC dispersions (1:5 $w / v$ in water) prepared via acid precipitation and enzyme treatment tested for their in vitro protein digestibility.

\subsubsection{In Vitro Gastro-Small Intestinal Digestion}

In vitro oral-gastro-small intestinal digestion was carried out on GPC dispersions using the method described by Chian, et al. [26]. All digestions were conducted at $37 \pm 1{ }^{\circ} \mathrm{C}$. Samples were drawn at 0,30 and 60 min of gastric digestion and $10 \mu \mathrm{L}$ of Pepstatin A (AB141416, Abcam Plc, New Zealand) was then added to every $\mathrm{mL}$ of digest collected.

For the small-intestinal digestion phase, digests were collected after 60 and $120 \mathrm{~min}$ of small-intestinal digestion. Protease inhibitor cocktail solution (SigmaFast ${ }^{\mathrm{TM}}$, Sigma 
Aldrich, Schnelldorf, Bavaria, Germany) ( $350 \mu \mathrm{L} / \mathrm{mL}$ digest) was then added to the digests collected. All digests were then stored at $-20{ }^{\circ} \mathrm{C}$ until further analysis.

\subsubsection{Soluble $\mathrm{N}$ and Free Amino N Contents}

The digests were centrifuged at $17,000 \times g$ for $10 \mathrm{~min}$ at $4{ }^{\circ} \mathrm{C}$ using a high-speed centrifuge (CR 22 GII, Himac, Hitachi Koki Co., Ltd., Ibaraki, Japan). The supernatant was then filtered through a $0.45 \mu \mathrm{m}$ PVDF filter. The supernatants were analysed for soluble protein (\%) and free amino nitrogen using the Kjeldahl method (as described in Section 2.4) and a colorimetric method to determine the ninhydrin-reactive amino nitrogen content, as described by Moore [27] and Kaur, et al. [28], respectively.

Results are presented as means of at least triplicate measurements \pm SD.

\section{Results \& Discussion}

\subsection{Protein Extraction Processes, GPC Yield (\%) and Composition}

The average yield of GPC powder obtained through acid precipitation was approximately $2.22 \%$ (fresh grass weight basis) and the protein content was $54.69 \%$.

We assumed that through enzyme hydrolysis via Viscozyme, structural cell wall components would be hydrolysed, releasing intracellular components such as chloroplasts containing RuBisCO. This could be the reason for the observed higher yield of GPC obtained when mechanical process was combined with enzyme treatment compared with mechanical disintegration alone (data not shown).

The optimum $\mathrm{pH}$ and temperature conditions for the activity of this multi-enzyme complex have been suggested to range between 3.3-5.5 and $40-50{ }^{\circ} \mathrm{C}$, respectively (Sigma Aldrich, Schnelldorf, Bavaria, Germany). The enzyme solution concentration used (1\%) was chosen based on literature $[16,29]$ and preliminary tests. The enzyme solution was added to the retentate at a ratio of 7:1 $(v / w)$ to obtain a mixture in enough liquid state to ensure continuous agitation by the overhead stirrer throughout the treatment.

Preliminary work by our research group has shown that the enzyme treatment did not improve protein extraction yield when the process lasted for less than $6 \mathrm{~h}$. Thus, a $6 \mathrm{~h}$ $(3+3 \mathrm{~h})$ treatment was chosen. The enzymatic treatment resulted in about $85 \%$ of grass proteins to be recovered. Viscozyme L might not be able to break some of the complex bonds between pectin and proteins [30] and thus prolonged enzyme treatment for $10 \mathrm{~h}$ showed no further effect on protein recovery (data not shown).

The protein content of the GPC obtained through the enzymatic process after freeze drying was $44 \%$ for the $6 \mathrm{~h}$ treatment. This indicated the presence of non-proteinaceous components in the GPC. The average yield of GPC obtained from this process was $11 \%$ (dry grass weight basis). The final powder obtained after grinding was homogeneous and green in colour as shown in (Figure 2).

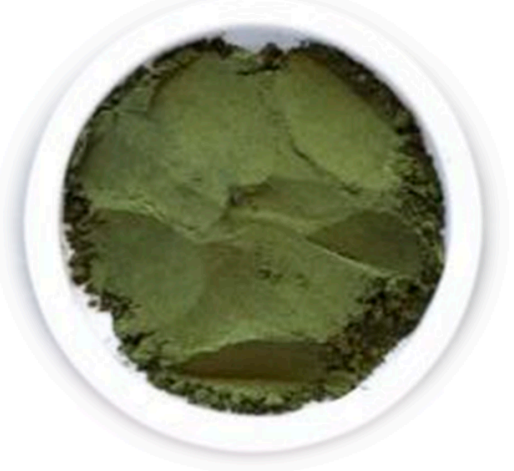

Figure 2. Grass Protein Concentrate prepared via enzyme extraction.

The GPC prepared by the acid precipitation method showed its protein and fat contents quite similar to a commercially available green-coloured Spirulina powder [31] while 
the sodium content was about six times lower than the latter (Table 1). It is also a significant source of other minerals including, calcium, potassium, magnesium and iron, suggesting the suitability of GPC as a dietary supplement.

Table 1. Proximate analysis of GPC extracted through acid precipitation.

\begin{tabular}{|c|c|}
\hline Component & Proportion $(\%$ or $\mathrm{mg} / 100 \mathrm{~g})$ \\
\hline \multicolumn{2}{|l|}{ Major components (\%) } \\
\hline Moisture & $3.77 \%$ \\
\hline Ash & $2.53 \%$ \\
\hline Protein & $54.69 \%$ \\
\hline Fat & $8.45 \%$ \\
\hline Carbohydrate & $26.61 \%$ \\
\hline Insoluble Dietary Fibre & $18.40 \%$ \\
\hline Soluble Dietary Fibre & $3.60 \%$ \\
\hline \multicolumn{2}{|l|}{ Minerals (mg/100 g) } \\
\hline Calcium & $143 \mathrm{mg} / 100 \mathrm{~g}$ \\
\hline Magnesium & $95 \mathrm{mg} / 100 \mathrm{~g}$ \\
\hline Potassium & $320 \mathrm{mg} / 100 \mathrm{~g}$ \\
\hline Sodium & $121 \mathrm{mg} / 100 \mathrm{~g}$ \\
\hline Iron & $40 \mathrm{mg} / 100 \mathrm{~g}$ \\
\hline
\end{tabular}

\subsection{Thermal Stability of the Grass Protein Concentrate}

When a protein is subjected to heat, it undergoes endothermic processes such as conformational changes and disruption of bonds, which unfolds and denatures the protein. Simultaneously, as heat is applied, forces such as hydrogen bonds and van der Waals forces that holds the protein's tertiary and quaternary structures are weakened. This exposes buried hydrophobic sites [32], causing aggregation of the protein molecules, which is an exothermic process. The differential scanning calorimeter (DSC) hence measures the net changes between the endo- and exothermic processes [33].

Raw GPC samples extracted through acid precipitation and enzymatic treatment were subjected to DSC analysis. Results obtained showed that the $\mathrm{T}_{\mathrm{d}}$ was $68.0 \pm 0.05^{\circ} \mathrm{C}$ and $66.15 \pm 0.03^{\circ} \mathrm{C}$ for samples prepared through acid precipitation and enzymatic treatment, respectively, which indicated that the GPCs extracted via different methods undergo conformational changes and unfold at different temperatures. This is in agreement with the studies conducted on RuBisCO obtained from other sources, such as alfalfa and tobacco. The protein RuBisCO from alfalfa displayed a $\mathrm{T}_{\mathrm{d}}$ of 61.85 to $72.85^{\circ} \mathrm{C}$ [34,35], depending on the experimental conditions utilised during the DSC measurements.

The enthalpies of denaturation of the GPC obtained via acid precipitation and enzyme treatment were determined to be $2.26 \pm 0.22 \mathrm{~J} / \mathrm{g}$ and $3.52 \pm 0.39 \mathrm{~J} / \mathrm{g}$, respectively. These values differ from the reported value of $26.3 \mathrm{~J} / \mathrm{g}$ from RuBisCO extracted from alfalfa [36]. This was speculated to be due to the presence of proteins other than $\mathrm{RuBisCO}$ and also to differences in $\mathrm{pH}$ of the GPC suspensions in the current study. Béghin, Bizot, Audebrand, Lefebvre, Libouga and Douillard [34] stated that the enthalpy of alfalfa RuBisCo decreased at $\mathrm{pH}$ below 7. This was attributed to a minimisation of intramolecular electrostatic repulsions near the isoelectric point. A lowering of protein-protein repulsion forces might have caused an irreversible aggregation which resulted in the observed differences in the thermal properties [37].

\subsection{Solubility of GPC}

Proteins that have high solubility allows for a uniform dispersion of protein particles to be obtained to form a good colloidal system. Proteins with high solubility have an increased number of potential applications in foods [38]. Hence, to determine the ability of the GPC to be utilised in food applications, it was solubilised under varying conditions, and the total soluble nitrogen content was plotted against the $\mathrm{pH}$, temperature and salt concentrations of the solutions. 


\subsubsection{Effect of $\mathrm{pH}$ on Protein Solubility}

When the $\mathrm{pH}$ of the GPC solution was varied, a significant effect on protein solubility was observed $(p<0.05)$, which indicates that the solubility is highly dependent on the $\mathrm{pH}$ of the environment (Figure 3). The protein solubility of GPC extracted by acid precipitation method was found to be lowest in the range of $\mathrm{pH} 3-5$, and it increased significantly when $\mathrm{pH}$ was increased up to 9 . According to several studies conducted on protein solubility, it has been concluded that a protein is least soluble at $\mathrm{pH}$ nearest to its isoelectric point [23] This is due to an increase in protein-protein interactions, as electrostatic forces of the protein molecules are at its lowest (no net electrical charges), leading to little water interaction with protein molecules. At this point, the proteins tend to aggregate, resulting in a decrease of protein solubility [39]. However, the minimum solubility experienced by the GPC in this study did not occur at the isoelectric point of pure RuBisCO, which is reported to be in the region of $\mathrm{pH} 4-6[6,40]$. This deviation may have occurred as the GPC sample used in this study was not a purified form of RuBisCO and may contain other forms of protein such as ATP synthase or protein kinase, which are proteins present in green leaves [41]. Similarly, the process used to obtain the GPC in this study might have differed from other studies. Different methods of obtaining RuBisCO, such as through thermal or $\mathrm{pH}$ denaturation, have been reported to affect its solubility $[33,42,43]$.

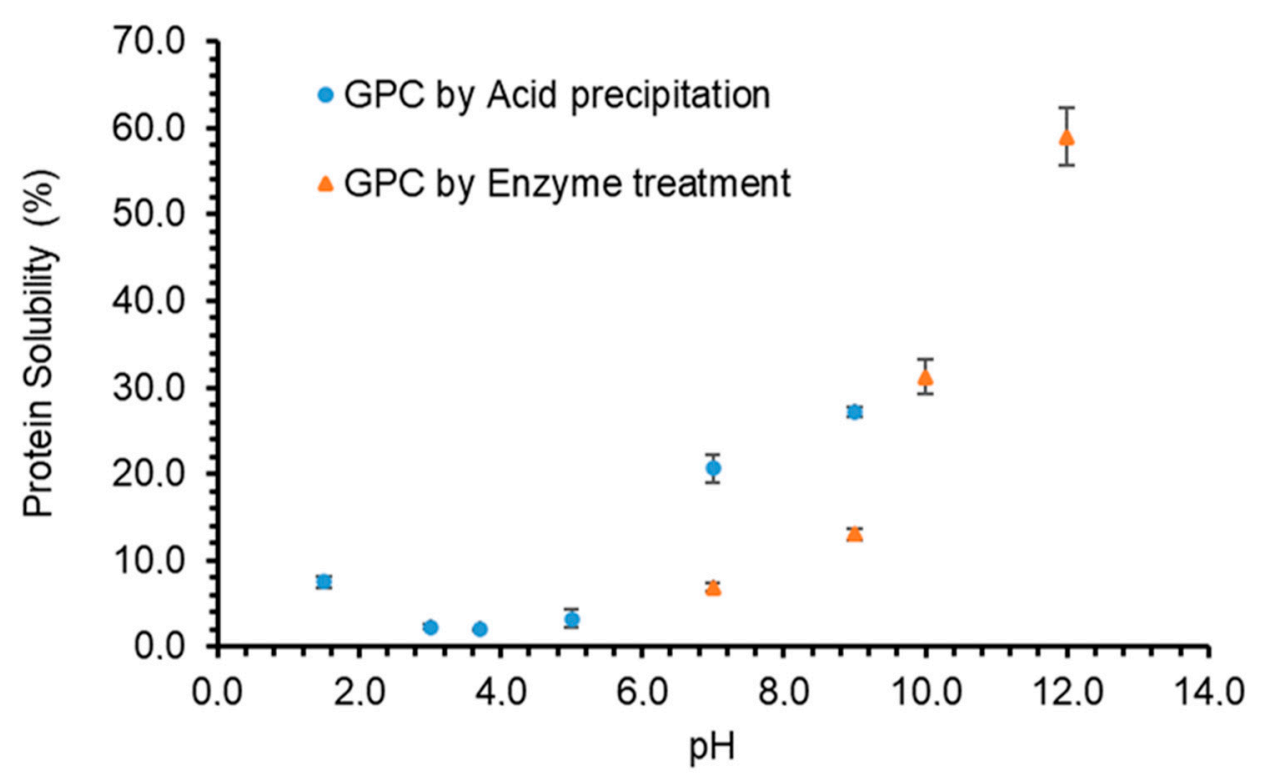

Figure 3. The effects of $\mathrm{pH}$ on protein solubility (\%) of grass protein concentrate (GPC) extracted through acid precipitation or enzyme treatment. Values are means $(n=3) \pm$ SD.

When $\mathrm{pH}$ of the GPC solution was increased, the solubility of GPC extracted by acid precipitation was found to be $20 \%$ and $27 \%$ at $\mathrm{pH} 7$ and 9 , respectively. On the other hand, the solubility of GPC extracted by enzyme treatment was only $6.8 \%$ and $13.3 \%$ at $\mathrm{pH} 7$ and 9, respectively. Nevertheless, GPC from enzyme treatment had better solubility in alkaline $\mathrm{pH}$ and it increased to $31.2 \%$ and $58.98 \%$ at $\mathrm{pH} 10$ and 12 , respectively at $20^{\circ} \mathrm{C}$. These results show that solubility is affected by the method of extraction. It has been reported that proteins obtained from leaf sources via various preparation methods have displayed a similar trend of having a higher protein solubility on either side of the isoelectric point $[33,42,44]$. Protein solubility of grass pea protein concentrate also reportedly decreased with a decrease in $\mathrm{pH}$ until $\mathrm{pH} 4-5$ followed by an increase with an increase in $\mathrm{pH}$ [4]. This is also observed in the solubility curve of the GPC, which is due to proteins acquiring net positive or negative charges when in acidic and basic environments. In alkaline environment, proteins acquire a total negative charge on their surfaces, and electrostatic 
repulsions between the molecules increase, decreasing protein-protein interactions and increasing the protein-water interactions, therefore the solubility [45].

To further improve the solubility of enzyme-extracted GPC at neutral $\mathrm{pH}$, the effect of the $\mathrm{pH}$-shifting process was studied. The $\mathrm{pH}$-shifting process involved subjecting the protein solution to an extreme acidic or alkaline $\mathrm{pH}$ condition and then to a neutral $\mathrm{pH}$ environment that allows the protein to undergo partial unfolding and then refolding to assume a molten globule conformation that has unique surface properties [46]. The solubility of the GPC extracted by enzyme treatment increased to $18.34 \%$ and $36.56 \%$ at neutral $\mathrm{pH}$ when the GPC was treated at $\mathrm{pH} 10$ and 12 , respectively at $20{ }^{\circ} \mathrm{C}$ (Figure 4). This unfolding-refolding phenomenon resulted in 5.3 times higher protein solubility at neutral $\mathrm{pH}$ for $\mathrm{pH}$ 12-treated samples as compared to samples at neutral $\mathrm{pH}$ without any $\mathrm{pH}$-shifting treatment. The unfolding-refolding phenomenon was described as an effective step in the modification of protein characteristics [46]. However, the structural changes appeared to primarily involve tertiary structure and could not be completely reversed with refolding treatment at $\mathrm{pH} 7$, thus producing a "molten globule" structure [47].

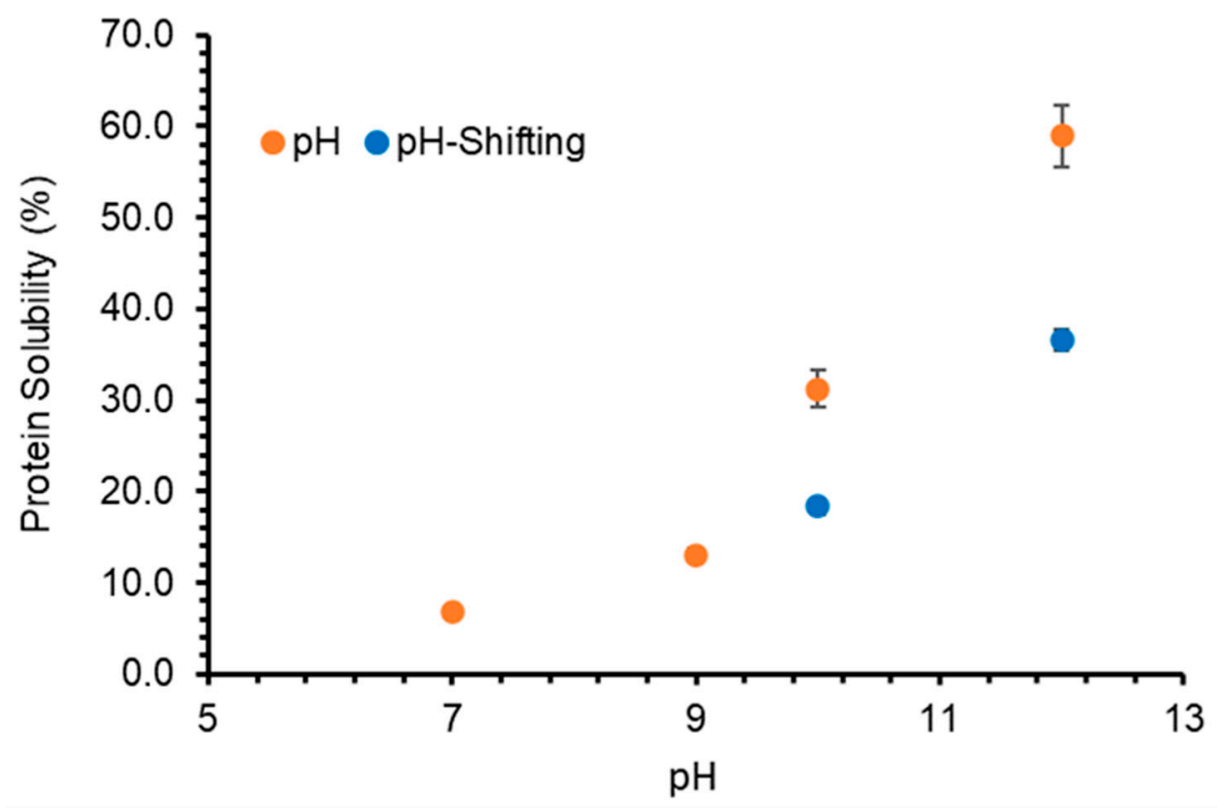

Figure 4. The effects of $\mathrm{pH}$-shift on protein solubility (\%) of grass protein concentrate (GPC) extracted through enzyme treatment. Values are means $(n=3) \pm \mathrm{SD}$.

\subsubsection{Effect of Temperature on Protein Solubility}

Protein solubility is highly dependent on protein-water interactions, which may be affected by the temperature of the medium the protein is subjected to. When GPC was subjected to a range of temperatures at neutral $\mathrm{pH}$, the solubility increased with increasing the temperature (Figure 5) indicating more protein-water interactions resulting in an increase in the solubility. Protein denaturation during thermal treatment have also been reported to result in weakening of hydrogen bonds and electrostatic forces that hold the protein's secondary, tertiary or quaternary structure together [23], which could also increase solubility. However, the solubility of GPC obtained by acid precipitation was found to decrease at temperatures higher than $80^{\circ} \mathrm{C}$. 


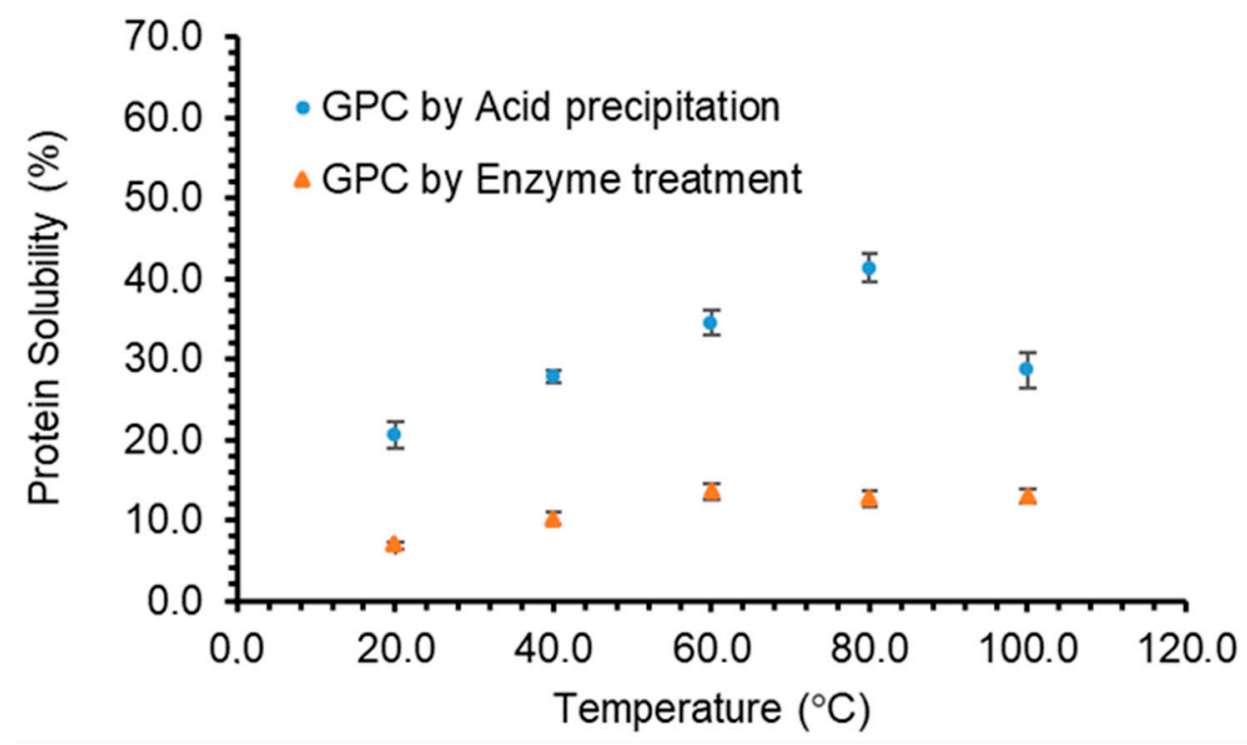

Figure 5. The effects of temperature on protein solubility (\%) of grass protein concentrate (GPC, $\mathrm{pH} 7)$ extracted through acid precipitation or enzyme treatment. Values are means $(n=3) \pm \mathrm{SD}$.

Similar results were observed for GPC extracted by enzyme treatment, where the solubility increased with an increase in the temperature up to $60^{\circ} \mathrm{C}$, at $\mathrm{pH} 7$ and 9 (Figure 6). However, when GPC was subjected to temperatures above $60^{\circ} \mathrm{C}$ the solubility remained stable, around $13 \%$ for $\mathrm{pH} 7$ and $44 \%$ for $\mathrm{pH} 9$. Likewise, when the temperature of the GPC sample, obtained by enzyme treatment treated with $\mathrm{pH}$-shifting process of $\mathrm{pH} 12$, was increased from $20^{\circ} \mathrm{C}$ to $60{ }^{\circ} \mathrm{C}$, the solubility increased from $36.56 \%$ to $48 \%$, and remained stabled above $60^{\circ} \mathrm{C}$ (Figure 6). This could be explained by the surface properties of proteins. The amount and distribution of hydrophilic and hydrophobic amino acid moieties on the surface may vary from one protein to another, which can have an impact on the behavior of a protein in solution $[23,48]$.

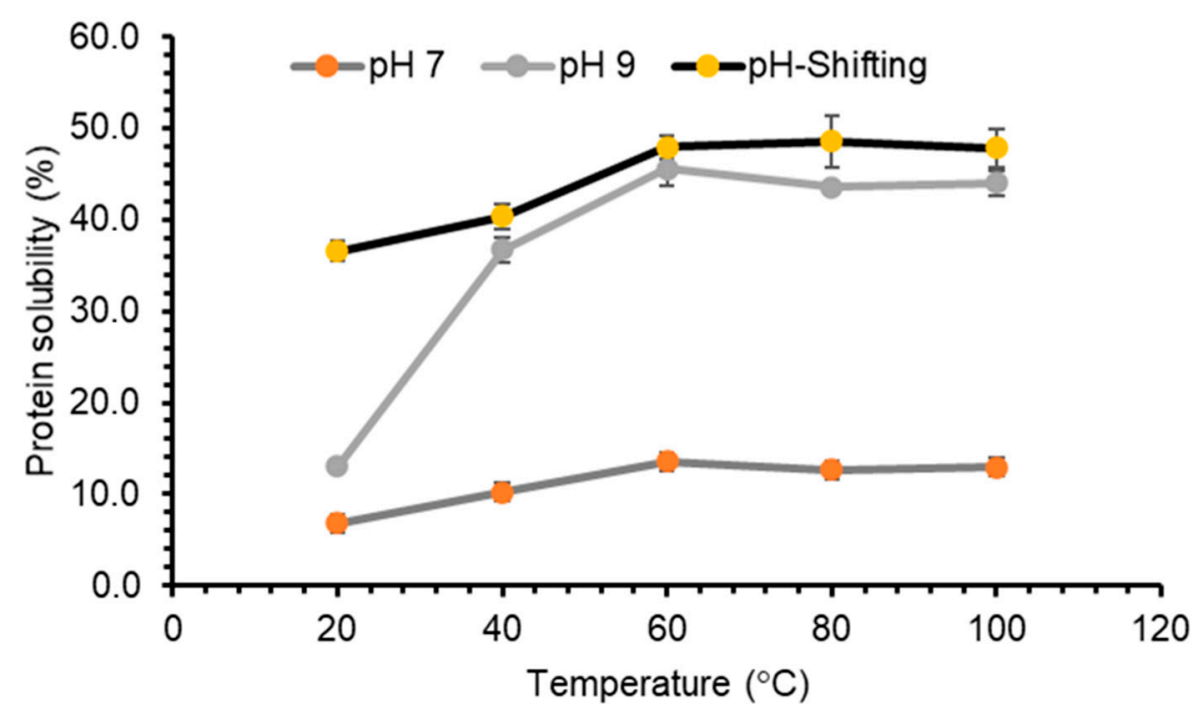

Figure 6. The effects of $\mathrm{pH}$-shift on protein solubility (\%) at different temperatures of grass protein concentrate (GPC) extracted through enzyme treatment. Values are means $(n=3) \pm \mathrm{SD}$.

\subsubsection{Effect of Salt Concentration on Protein Solubility}

The solubility of protein could be affected by the ionic valence, concentration, and the type of ions dissociated by the salts added in the solution. When the concentration of sodium chloride in GPC solution was increased, it resulted in a significant decrease 
$(p<0.05)$ in the protein solubility as shown in (Figure 7). Salting out phenomenon was observed, whereby an increase in salt content led to a decrease in protein solubility. This occurred due to ions being dissociated into the solution, which might have reduced the electrostatic repulsive interactions between the charged protein molecules [49]. Hence, as more salt was added into the solution, more ions were dissociated which led to a greater reduction in the repulsion forces between the protein molecules, causing aggregation and precipitation of the proteins from the solution, decreasing its solubility.

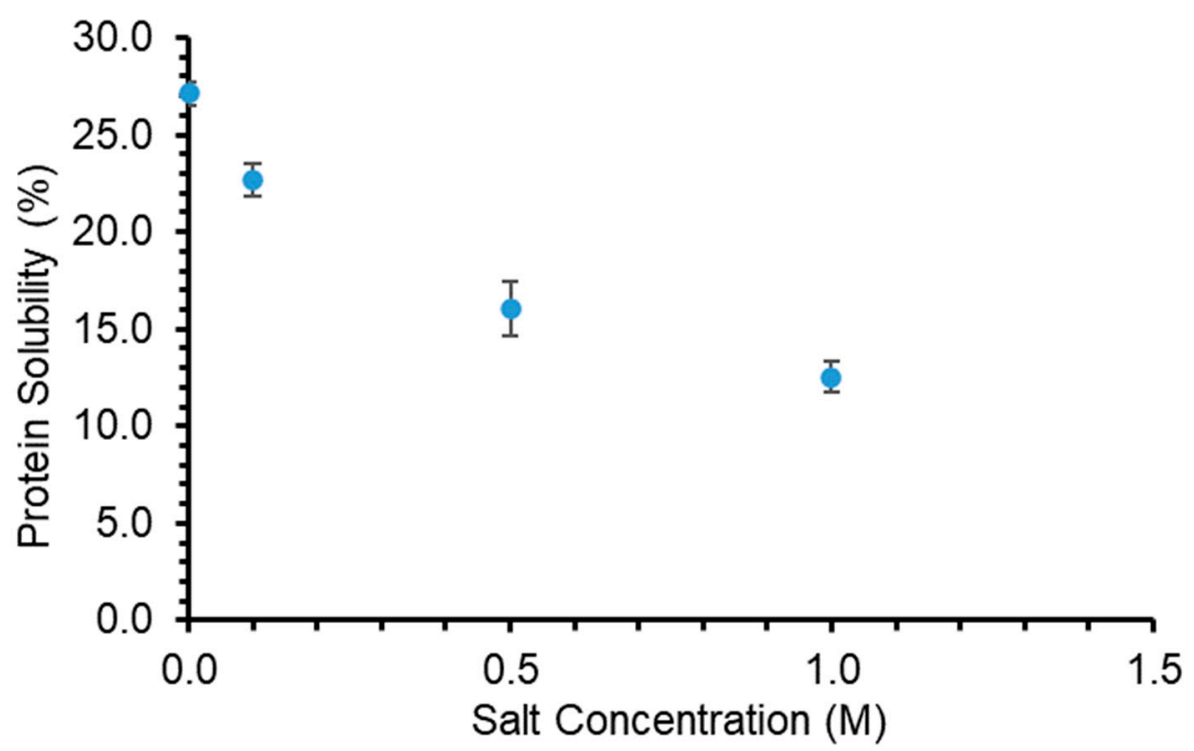

Figure 7. The effects of salt $(\mathrm{NaCl})$ concentration $(\mathrm{M})$ on protein solubility $(\%)$ of grass protein concentrate (GPC) extracted through acid precipitation. Values are means $(n=3) \pm \mathrm{SD}$.

\subsection{In Vitro Protein Digestibility of GPC}

\subsubsection{Soluble Nitrogen Content during Digestion}

For the raw GPC prepared via either enzymatic or acid treatment, during the stomach phase of the digestion, protein solubility was poor (Figure 8). But the solubility increased significantly during the small-intestinal digestion phase. However, GPC prepared by acid precipitation had significantly $(p<0.05)$ higher solubility compared with digests from enzyme-treated GPC during both gastric and small-intestinal digestion phases.

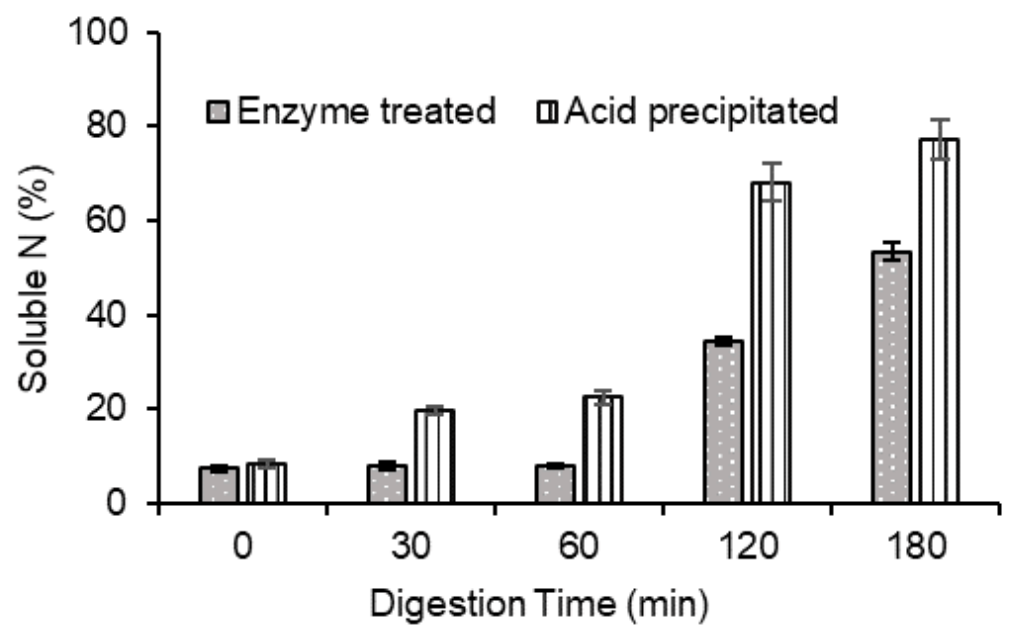

Figure 8. Cont. 


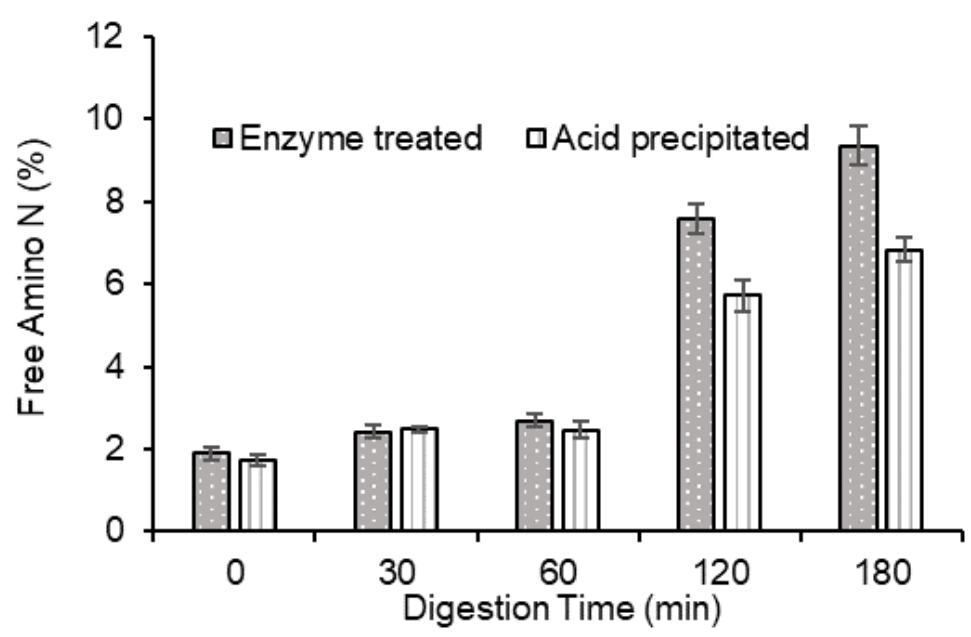

Figure 8. Soluble N (\%, above) and Free amino N (\%, below) during in vitro gastro (0, 30, $60 \mathrm{~min})$ small intestinal $(120,180 \mathrm{~min})$ protein digestion for GPC extracted via acid or enzyme treatment. Values are means $(n=3) \pm \mathrm{SD}$.

\subsubsection{Free Amino Nitrogen Content}

Overall, GPC displayed lower ninhydrin reactive free amino $\mathrm{N}$ values than those reported for muscle proteins [26,28]. High protein digestibility value has been attributed to the ease of access of the protease to the peptide bonds aided by a lower amount of non-protein materials [50]. Thus, increasing the purity of the GPC might also improve the digestibility of grass proteins. As seen in (Table 1), GPC contains a significant amount of insoluble dietary fibre (DF). Dietary fibre has been shown to affect processes that occur throughout the gastro-intestinal tract. The composition of cell walls, which is the main dietary fibre in plants, could affect the digestion process in the small intestine. Insoluble DF has been reported not to have a large impact on nutrient absorption while the presence of DF could decrease protein digestibility [51,52]. In a study conducted on rapeseed, the presence of various sources and amounts of DF reduced the in vitro protein digestibility of napin proteins, which was associated with a lowered proteolytic enzymatic activity during the in vitro protein digestion process [53]. A reduced enzyme to substrate contact was also reported to have possibly occurred due to the presence of DF [53]. Therefore, the low in vitro protein digestibility observed for GPC could be attributed to the presence of non-protein substances, particularly high insoluble dietary fibre content of GPC.

The free amino $\mathrm{N}$ values obtained after digestion of GPC prepared by enzyme treatment were significantly higher than those obtained for GPC prepared by acid precipitation.

\section{Conclusions}

The chemical composition of GPC (prepared by acid precipitation), particularly its protein and fat contents, was observed to be close to blue-green algae based commercial product (Spirulina), which is commonly used as a dietary supplement. GPC could also be a good source of other minerals such as calcium, potassium, magnesium and iron. The solubility of the grass protein concentrate was found to be significantly affected by the method of protein extraction, $\mathrm{pH}$, temperature and salt concentration of the solution. The thermal denaturation temperature and enthalpy of the extracted GPC also differed among the two protein extraction methods-acid precipitation and enzymatic extraction. The in vitro protein digestibility of the GPC, assessed in terms of free amino $\mathrm{N}$ release during digestion, was observed to be quite low during the gastric digestion phase but increased during small-intestinal digestion phase. This was possibly related to the increase of the solubility of the GPC during the latter phase of digestion. Changes in protein solubility of GPC dispersions through the use of surfactants will be studied in the future as these amphiphilic molecules tend to bind to proteins, shielding their hydrophobic regions, thereby increasing solubility. The use of innovative technologies, including the 
use of ultrasound and pulsed electric fields, alone and in combination with the traditional extraction methods could be explored in the future to improve the yield and functional characteristics of the protein concentrates from grass.

Author Contributions: Conceptualization, L.K., and J.S.; methodology, I.F.L., L.K., and J.S.; software, H.L., D.O.S.M., and M.F.; validation, H.L., and L.K.; formal analysis, K.A.-S., H.L., D.O.S.M., and M.F.; investigation, K.A.-S., H.L., D.O.S.M., M.F., L.K., and J.S.; resources, I.F.L., L.K., and J.S.; data curation, H.L., D.O.S.M., M.F., and L.K.; writing-original draft preparation, L.K., D.O.S.M., and M.F.; writing-review and editing, H.L., D.O.S.M., M.F., L.K., I.F.L., and J.S.; visualization, L.K., I.F.L., and J.S.; supervision, L.K., and J.S.; project administration, L.K., and J.S.; funding acquisition, L.K., and J.S. All authors have read and agreed to the published version of the manuscript.

Funding: Funding by Riddet CoRE, New Zealand and Massey University Research Funding (MURF) is gratefully acknowledged.

Institutional Review Board Statement: Not Applicable.

Informed Consent Statement: Not applicable.

Data Availability Statement: The data are available on request from the corresponding author, (J.S.).

Acknowledgments: The authors would also like to thank Mark Osborne from the School of Agriculture and Environment, Massey University (Palmerston North, NZ) for helping with obtaining grass samples for the study.

Conflicts of Interest: The authors have no conflicts of interest to declare.

\section{References}

1. Hoehnel, A.; Axel, C.; Bez, J.; Arendt, E.K.; Zannini, E. Comparative analysis of plant-based high-protein ingredients and their impact on quality of high-protein bread. J. Cereal Sci. 2019, 89, 102816. [CrossRef]

2. Barbeau, W.E.; Kinsella, J.E. Ribulose bisphosphate carboxylase/oxygenase (rubisco) from green leaves-potential as a food protein. Food Rev. Int. 1988, 4, 93-127. [CrossRef]

3. Solati, Z.; Manevski, K.; Jørgensen, U.; Labouriau, R.; Shahbazi, S.; Lærke, P.E. Crude protein yield and theoretical extractable true protein of potential biorefinery feedstocks. Ind. Crops Prod. 2018, 115, 214-226. [CrossRef]

4. Hayati Zeidanloo, M.; Ahmadzadeh Ghavidel, R.; Ghiafeh Davoodi, M.; Arianfar, A. Functional properties of Grass pea protein concentrates prepared using various precipitation methods. J. Food Sci. Technol. 2019, 56, 4799-4808. [CrossRef]

5. Di Stefano, E.; Agyei, D.; Njoku, E.N.; Udenigwe, C.C. Plant RuBisCo: An underutilized protein for food applications. J. Am. Oil Chem. Soc. 2018, 95, 1063-1074. [CrossRef]

6. Sheen, S.J.; Sheen, V.L. Functional properties of fraction 1 protein from tobacco leaf. J. Agric. Food Chem. 1985, 33, 79-83. [CrossRef]

7. Amer, B.; Juul, L.; Møller, A.H.; Møller, H.S.; Dalsgaard, T.K. Improved solubility of proteins from white and red clover-Inhibition of redox enzymes. Int. J. Food Sci. Technol. 2021, 56, 302-311. [CrossRef]

8. Pojić, M.; Mišan, A.; Tiwari, B. Eco-innovative technologies for extraction of proteins for human consumption from renewable protein sources of plant origin. Trends Food Sci. Technol. 2018, 75, 93-104. [CrossRef]

9. Azmir, J.; Zaidul, I.; Rahman, M.; Sharif, K.; Mohamed, A.; Sahena, F.; Jahurul, M.; Ghafoor, K.; Norulaini, N.; Omar, A. Techniques for extraction of bioactive compounds from plant materials: A review. J. Food Eng. 2013, 117, 426-436. [CrossRef]

10. Wu, K.; Ju, T.; Deng, Y.; Xi, J. Mechanochemical assisted extraction: A novel, efficient, eco-friendly technology. Trends Food Sci. Technol. 2017, 66, 166-175. [CrossRef]

11. Nadar, S.S.; Rao, P.; Rathod, V.K. Enzyme assisted extraction of biomolecules as an approach to novel extraction technology: A review. Food Res. Int. 2018, 108, 309-330. [CrossRef] [PubMed]

12. Selvamuthukumaran, M.; Shi, J. Recent advances in extraction of antioxidants from plant by-products processing industries. Food Qual. Saf. 2017, 1, 61-81. [CrossRef]

13. Shen, L.; Wang, X.; Wang, Z.; Wu, Y.; Chen, J. Studies on tea protein extraction using alkaline and enzyme methods. Food Chem. 2008, 107, 929-938. [CrossRef]

14. Agriseeds. Trojan Perennial Ryegrass; Barenbrug: Christchurch, New Zealand, 2013.

15. Joint FAO/WHO Food Standards Programme Codex Alimentarius Commission. General standard for vegetable protein products (VPP) CXS 174-1989. In Codex Alimentarius/Joint FAO/WHO Food Standards Programme, Codex Alimentarius Commission; Food and Agriculture Organization of the United Nations, World Health Organization: Rome, Italy, 2019; Adopted in 1989, Amended in 2019 .

16. de Figueiredo, V.R.G.; Yamashita, F.; Vanzela, A.L.L.; Ida, E.I.; Kurozawa, L.E. Action of multi-enzyme complex on protein extraction to obtain a protein concentrate from okara. J. Food Sci. Technol. 2018, 55, 1508-1517. [CrossRef]

17. Zhang, C.; Sanders, J.P.M.; Bruins, M.E. Critical parameters in cost-effective alkaline extraction for high protein yield from leaves. Biomass Bioenergy 2014, 67, 466-472. [CrossRef] 
18. Horwitz, W. (Ed.) Official Methods of Analysis of AOAC International. Volume I, Agricultural Chemicals, Contaminants, Drugs; AOAC International: Gaithersburg, MD, USA, 1997.

19. Jiang, B.; Tsao, R.; Li, Y.; Miao, M. Food Safety: Food Analysis Technologies/Techniques; Elsevier: Amsterdam, The Netherlands, 2014.

20. Singh, J.; McCarthy, O.J.; Singh, H.; Moughan, P.J.; Kaur, L. Morphological, thermal and rheological characterization of starch isolated from New Zealand Kamo Kamo (Cucurbita pepo) fruit-A novel source. Carbohydr. Polym. 2007, 67, 233-244. [CrossRef]

21. Ahmad, S.; Nema, P.; Bashir, K. Effect of different drying techniques on physicochemical, thermal, and functional properties of seera. Dry. Technol. 2018, 36, 1284-1291. [CrossRef]

22. Bolontrade, A.J.; Scilingo, A.A.; Añón, M.C. Amaranth proteins foaming properties: Adsorption kinetics and foam formationPart 1. Colloids Surf. B Biointerfaces 2013, 105, 319-327. [CrossRef]

23. Pelegrine, D.; Gasparetto, C. Whey proteins solubility as function of temperature and pH. LWT Food Sci. Technol. 2005, 38, 77-80. [CrossRef]

24. Hamm, R.; Deatherage, F.E. Changes in hydration, solubility and charges of muscle proteins during heating of meat ${ }^{\text {a }}$. J. Food Sci. 1960, 25, 587-610. [CrossRef]

25. Yildiz, G. Effect of $\mathrm{pH}$-shifting method on solubility and emulsifying properties of soy protein concentrate. Harran Tarım Grda Bilimleri Derg. 2018, 23, 159-166. [CrossRef]

26. Chian, F.M.; Kaur, L.; Oey, I.; Astruc, T.; Hodgkinson, S.; Boland, M. Effect of Pulsed Electric Fields (PEF) on the ultrastructure and in vitro protein digestibility of bovine longissimus thoracis. LWT 2019, 103, 253-259. [CrossRef]

27. Moore, S. Amino acid analysis: Aqueous dimethyl sulfoxide as solvent for the ninhydrin reaction. J. Biol. Chem. 1968, 243, 6281-6283. [CrossRef]

28. Kaur, L.; Astruc, T.; Vénien, A.; Loison, O.; Cui, J.; Irastorza, M.; Boland, M. High pressure processing of meat: Effects on ultrastructure and protein digestibility. Food Funct. 2016, 7, 2389-2397. [CrossRef]

29. Hanmoungjai, P.; Pyle, D.L.; Niranjan, K. Enzyme-assisted water-extraction of oil and protein from rice bran. J. Chem. Technol. Biotechnol. Int. Res. Process Environ. Clean Technol. 2002, 77, 771-776. [CrossRef]

30. Cheng, X.; Bi, L.; Zhao, Z.; Chen, Y. Advances in enzyme assisted extraction of natural products. In Proceedings of the 3rd International Conference on Material, Mechanical and Manufacturing Engineering (IC3ME 2015), Guangzhou, China, 27-28 June 2015.

31. Healtheries, N.Z. Spirulina: Typical Nutrient Analysis. Available online: https://healtheries.co.nz/product/spirulina-powder (accessed on 12 January 2021).

32. Farkas, J.; Mohácsi-Farkas, C. Application of differential scanning calorimetry in food research and food quality assurance. J. Therm. Anal. Calorim. 1996, 47, 1787-1803. [CrossRef]

33. Lamsal, B.; Koegel, R.; Gunasekaran, S. Some physicochemical and functional properties of alfalfa soluble leaf proteins. LWT-Food Sci. Technol. 2007, 40, 1520-1526. [CrossRef]

34. Béghin, V.; Bizot, H.; Audebrand, M.; Lefebvre, J.; Libouga, D.G.; Douillard, R. Differential scanning calorimetric studies of the effects of ions and $\mathrm{pH}$ on ribulose 1,5-bisphosphate carboxylase/oxygenase. Int. J. Biol. Macromol. 1993, 15, 195-200. [CrossRef]

35. Burova, T.; Soshinsky, A.; Danilenko, A.; Antonov, Y.A.; Grinberg, V.Y.; Tolstoguzov, V. Conformation stability of ribulosodiphosphatecarboxylase of alfalfa green leaves according to the data of differential scanning microcalorimetry. Biofizika 1989, 34, 545-549.

36. Tomimatsu, Y. Macromolecular properties and subunit interactions of ribulose-1,5-bisphosphate carboxylase from alfalfa. Biochim. Biophys. Acta Protein Struct. 1980, 622, 85-93. [CrossRef]

37. Privalov, P.L.; Potekhin, S.A. Scanning microcalorimetry in studying temperature-induced changes in proteins. In Methods in Enzymology; Elsevier: Amsterdam, The Netherlands, 1986; Volume 131, pp. 4-51.

38. Zayas, J.F. Solubility of proteins. In Functionality of Proteins in Food; Springer: Berlin/Heidelberg, Germany, $1997 ;$ pp. 6-75.

39. Damodaran, S.; Parkin, K.L.; Fennema, O.R. Fennema's Food Chemistry, 4th ed.; CRC Press: Boca Raton, FL, USA, 2007.

40. Knuckles, B.E.; Kohler, G.O. Functional properties of edible protein concentrates from alfalfa. J. Agric. Food Chem. 1982, 30, 748-752. [CrossRef]

41. Xue, L.; Ren, H.; Li, S.; Gao, M.; Shi, S.; Chang, E.; Wei, Y.; Yao, X.; Jiang, Z.; Liu, J. Comparative proteomic analysis in Miscanthus sinensis exposed to antimony stress. Environ. Pollut. 2015, 201, 150-160. [CrossRef]

42. Betschart, A.A. Nitrogen solubility of alfalfa protein concentrate as influenced by various factors. J. Food Sci. 1974, 39, 1110-1115. [CrossRef]

43. Miller, R.E.; De Fremery, D.; Bickoff, E.; Kohler, G.O. Soluble protein concentrate from alfalfa by low-temperature acid precipitation. J. Agric. Food Chem. 1975, 23, 1177-1179. [CrossRef]

44. Wang, J.; Kinsella, J. Functional properties of novel proteins: Alfalfa leaf protein. J. Food Sci. 1976, 41, 286-292. [CrossRef]

45. Machado, F.F.; Coimbra, J.S.; Rojas, E.E.G.; Minim, L.A.; Oliveira, F.C.; Rita de Cássia, S.S. Solubility and density of egg white proteins: Effect of $\mathrm{pH}$ and saline concentration. LWT Food Sci. Technol. 2007, 40, 1304-1307. [CrossRef]

46. Jiang, J.; Zhu, B.; Liu, Y.; Xiong, Y.L. Interfacial structural role of $\mathrm{pH}$-shifting processed pea protein in the oxidative stability of oil/water emulsions. J. Agric. Food Chem. 2014, 62, 1683-1691. [CrossRef]

47. Jiang, J.; Chen, J.; Xiong, Y.L. Structural and emulsifying properties of soy protein isolate subjected to acid and alkaline $\mathrm{pH}$-shifting processes. J. Agric. Food Chem. 2009, 57, 7576-7583. [CrossRef] [PubMed] 
48. Lam, A.; Can Karaca, A.; Tyler, R.; Nickerson, M. Pea protein isolates: Structure, extraction, and functionality. Food Rev. Int. 2018, 34, 126-147. [CrossRef]

49. Mu, T.H.; Tan, S.S.; Chen, J.W.; Xue, Y.L. Effect of $\mathrm{pH}$ and $\mathrm{NaCl} / \mathrm{CaCl}_{2}$ on the solubility and emulsifying properties of sweet potato protein. J. Sci. Food Agric. 2009, 89, 337-342. [CrossRef]

50. Aderinola, T.A.; Alashi, A.M.; Nwachukwu, I.D.; Fagbemi, T.N.; Enujiugha, V.N.; Aluko, R.E. In vitro digestibility, structural and functional properties of Moringa oleifera seed proteins. Food Hydrocoll. 2020, 101, 105574. [CrossRef]

51. Eggum, B.O. The influence of dietary fibre on protein digestion and utilization in monogastrics. Arch. Für Tierernahr. 1995, 48, 89-95. [CrossRef] [PubMed]

52. Kritchevsky, D. Dietary Fiber. Annu. Rev. Nutr. 1988, 8, 301-328. [CrossRef] [PubMed]

53. Joehnke, M.S.; Sørensen, S.; Bjergegaard, C.; Markedal, K.E.; Sørensen, J.C. Effect of dietary fibre fractions on in vitro digestibility of rapeseed napin proteins. Pol. J. Food Nutr. Sci. 2018, 68, 335-345. [CrossRef] 